\title{
Święci władcy jako kategoria świętości w prawosławiu*
}

\author{
Jarosław Charkiewicz \\ Warszawska Metropolia Prawosławna \\ Polska \\ jarek@cerkiew.pl
}

Jarosław Charkiewicz, Saint rulers as a category of sanctity in Orthodoxy, Elpis, 17 2015: 25-29.

\begin{abstract}
In the wide spectre of Orthodox human sanctity, among others, there is also a category of saint rulers. Despite the fact that it's represented by a significant number of saints, it remains, utterly undeservedly, in the shadow of the others - more known or more deeply rooted historically. On top of that, the situation may result as well from the fact that saint rulers, as a distinct category of saint, are not separately mentioned neither during the proskomedia, nor during the intercessory prayer of the anaphora. Still, the saint rulers definitely should be considered a separate type of sanctity, deserving a somehow wider presentation. Such is therefore the aim of this article.

It is also an attempt of suggesting an interior systematic of this category of sanctity. Preserving, appearing in science, classifications of the saint rulers, the author gives also his own proposition. In the category of saint rulers there are four following groups: (1) rulers who weren't neither martyrs nor monks or passion-bearers, (2) rulers who died martyrs, (3) rulers who long before their death became monks and led monastic life, (4) rulers-passion-bearers.
\end{abstract}

Streszczenie: W szerokiej gamie prawosławnej świętości ludzkiej znajduje się m.in. kategoria świętych władców. Chociaż reprezentowana jest ona przez stosunkowo znaczną liczbę świętych, to niezasłużenie pozostaje w cieniu innych - tych bardziej znanych czy posiadających głębsze korzenie historyczne. Dodatkowo sytuacja taka może być również związana z tym, że święci władcy, jako oddzielna kategoria świętych, nie są osobno wspominani ani podczas proskomidii, ani w czasie modlitwy wstawienniczej anafory. Mimo to święci władcy z pewnością powinni być traktowani jako osobny typ świętości, zasługujący na nieco szersze omówienie. To też cel stawia przed sobą niniejszy artykuł.

Jest on ponadto próbą zaproponowania wewnętrznej systematyki tej kategorii świętości. Przedstawiając występujące w nauce klasyfikacje prawowiernych, autor przedstawia również swoją propozycję. W ramach kategorii świętych władców wyodrębniane są następujące cztery grupy: (1) władcy nie będący ani męczennikiem, ani stanu monastycznego, ani cierpiętnikiem, (2) władcy, którzy zakończyli swoje życie śmiercią męczeńską, (3) władcy, którzy nie na łożu śmierci, lecz wcześniej złożyli śluby monastyczne i wiedli żywot mnisi, oraz (4) władcy-cierpiętnicy.

Keywords: saints, saint rulers, passion-bearers, category of sanctity

Słowa kluczowe: święci, władcy, prawowierni, cierpiętnicy, kategoria świętości

W szerokiej gamie prawosławnej świętości ludzkiej znajduje się m.in. kategoria świętych władców. Chociaż reprezentowana jest ona przez stosunkowo znaczną liczbę świętych, to niezasłużenie pozostaje w cieniu innych - tych bardziej znanych czy posiadających głębsze korzenie historyczne. Dodatkowo sytuacja taka może być również związana z tym, że święci władcy, jako oddzielna kategoria świętych, nie są osobno wspominani ani podczas proskomidii, ani w czasie modlitwy wstawienniczej anafory. Mimo to święci władcy z pewnością powinni być traktowani jako osobny typ świętości, zasługujący na nieco szersze omówienie. To też cel stawia przed sobą niniejszy artykuł, będący ponadto próbą zaproponowania wewnętrznej systematyki tej kategorii świętości.

W terminologii prawosławnej święci władcy nazywani

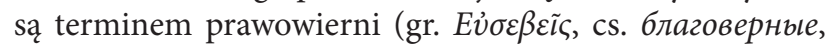
ang. Right believing). Jest to kategoria świętości, do której należą kanonizowani władcy, osoby obojga płci sprawują- ce świecką władzę nad innymi ludźmi: cesarze, królowie, książęta, itd. ${ }^{1}$

Teologiczna podstawa oddawania czci niektórym monarchom jako świętym opiera się na postrzeganiu ich jako osób, które z woli Bożej sprawują władzę nad innymi, pomagając im w prowadzeniu życia, strzegąc praw i sądząc poddanych. Takie pojmowanie służby monarchy posiada korzenie starotestamentowe (por. 1 Sam 10,6 oraz wielokrotnie podkreślane wybraństwo króla Dawida)2.

Sam status władcy, zgodnie z wyrażeniem cesarza Kon-

\footnotetext{
* Projekt został sfinansowany ze środków Narodowego Centrum Nauki przyznanych na podstawie decyzji numer DEC-2012/07/N/HS1/01570.

1 Termin „prawowierny” używany był również jako epitet używany w doksologiach na cześć cesarzy rzymskich i bizantyjskich, a w Rosyjskim Kościele Prawosławnym wobec hierarchów jako synonim terminu „prawosławny”, I.I. Srezniewski, Materiaty dla słowaria drewnierusskogo jazyka po pismiennym pamjatnikam, Sankt Petersburg 1893, t. I, kol. 92.

2 E. N. Nikulina, Agiołogija, Moskwa 2009, s. 241.
} 
stantyna Wielkiego, „postawionego przez Boga biskupem spraw zewnętrznych Kościoła"', pozwalał stosować wobec niego przymiotnik „prawowierny”, tj. „wyznający prawdziwą (tj. prawosławną) wiarę"4. Monarcha musiał jednak spełniać dwa warunki: nie mógł być heretykiem, a w swych działaniach musiał kierować się poczuciem sprawiedliwości ${ }^{5}$. Nie bez znaczenia była również pobożność władcy w Bizancjum, w kompetencjach którego leżało m.in. zwoływania soborów kościelnych i inicjowanie dyskusji w kwestiach dogmatycznych. Podkreśla to Andrej Zajcew w swojej definicji prawowiernych akcentuje nie tyle ich „uwieńczoną sukcesami działalność polityczną" czy „ideę monarszej władzy samą z siebie", co kwestię tego, na ile dany władca sprawując władzę zbliżył się do ewangelicznego ideału ${ }^{6}$. Podobnie Wiktor Żywow pisze o prawowiernych, że jest to „typ świętości monarchów, którzy zasłynęli swą pobożnością, miłosierdziem oraz troską o umocnienie wiary chrześcijańskiej”' . Autor ten dalej zaznacza również, że „oddawanie czci cesarzom jako świętym jest oparte na wyborze i powstaje zwykle, podobnie jak w przypadku innych świętych, w rezultacie wychwalenia ich ze względu na dar czynienia cudów"s.

Kult prawowiernych obecny jest w Kościele od schyłku IV wieku. Datą graniczną wydaje się być rok 380, gdy chrześcijaństwo w Cesarstwie Bizantyjskim zostało uznane za religię państwową. Kult ten jest zatem późniejszy w porównaniu z czcią oddawaną apostołom, męczennikom, wyznawcom, świętym hierarchom i świątobliwym? 9

Już od pierwszych wieków chrześcijaństwa było oczywiste, że szczególna pozycja, jaką zajmował monarcha $\mathrm{w}$ strukturze społecznej nie musiała $\mathrm{z}$ góry oznaczać jego świętości. Leżące w gestii cesarzy bizantyjskich kompetencje do podejmowania działań w sferze kościelnej (w tym możliwość zwoływania soborów), sprzyjały jednak możliwości docenienia ich wkładu w życie Kościoła, szczególnie w walce z szerzącymi się fałszywymi naukami. Szczególną czcią otaczano wówczas głównie tych władców, którzy „,okazali Kościołowi pomoc w walce $\mathrm{z}$ herezjami w epoce Soborów Powszechnych"10. Niemal zasadą stały się kanonizacje cesarzy, za panowania których zwoływane były kolejne sobory: Konstantyna Wielkiego (zwołał I Sobór Powszechny w 325 r.), Teodozjusza Wielkiego (II - 381), Teodozjusza II (III - 431), Pulcherii (IV - 451), Justyniana Wielkiego

\footnotetext{
Euzebiusz z Cezarei, Życie Konstantyna, wstęp, przekł. T. Wnętrzak, ŹMT 44, Kraków 2007, s. 7.

4 A. Znosko, ks., Słownik cerkiewnosłowiańsko-polski, Białystok 1996, s. 22.

5 Por. Andronik (Trubaczow), ihumen, (hasło) Błagowiernyj, [w:] Prawosławnaja encikłopiedija, t. 5, Moskwa 2002, s. 251.

6 A. Zajcew, Żitija swjatych. Putiewoditiel', Moskwa 2008, s. 98.

W.M. Żywow, Swjatost'. Kratkij słowar' agiograficzeskich terminow, Moskwa 1994, s. 21.

8 Tamże. Autor podaje w tym miejscu przykład św. cesarzowej Teofanii (+894), pierwszej żony cesarza Leona Mądrego, cuda przy grobie której już w kilka dni po jej śmierci, stały się głównym powodem zaliczenia jej do grona świętych.

9 Por. Biskup Hilarion Ałfiejew, Prawosławie, t. I, Moskwa 2008, s. 710.

10 G. Fiedotow, Święci Rusi (X-XVII w.), przekł. ks. H. Paprocki, Białystok - Bydgoszcz 2002, s. 74; por. Andronik (Trubaczow), ihumen, (hasło) Błagowiernyj, s. 251.
}

(V - 553), Ireny (VII - 787). Głównie też za zasługi wobec Kościoła do grona świętych włączono cesarzowe Helenę (+327), która odnalazła Krzyż Pański oraz Teodorę (+867), która przywróciła i umocowała kult świętych wizerunków w Kościele ${ }^{11}$. Spośród władców w kalendarzach wschodnich najwcześniej pojawiły się imiona cesarza Konstantyna Wielkiego oraz jego matki cesarzowej Heleny. Tym samym w kanonizacji władców z Kościele Bizantyjskim „znalazł odbicie ideał teokratycznej posługi cesarza"12.

Świętych władców w tym okresie otaczano zatem czcią głównie z tytułu tego, że okazali Kościołowi pomoc w walce $\mathrm{z}$ herezjami w epoce Soborów Powszechnych ${ }^{13}$. Jednak od tej niepisanej reguły istniały dwojakiego rodzaju wyjątki. Kilka monarchiń, jak np. cesarzowa Pulcheria, dostąpiło kanonizacji za wyjątkowo ascetyczne życie. Kilku monarchów zaś, np. cesarz Leon I Wielki, nie tylko za ich zasługi dla Kościoła, co przede wszystkim pobożność i przykład własnego życia ${ }^{14}$.

Wśród dziewiętnastu władców bizantyjskich, których imiona znajdują się obecnie w greckich kalendarzach i żyjących do czasu powstania Menologionu cesarza Bazylego II (976-1025), tylko siedmiu weszło do tego kalendarza z czcią ogólnokościelną. Pozostali prawdopodobnie otoczeni byli jedynie kultem lokalnym, w granicach tych Kościołów lokalnych, na terenie których znajdowały się ich relikwiarze, i do kalendarzy zostali wpisani nie wcześniej niż w XII wieku ${ }^{15}$.

W tradycji ruskiej kult świętych monarchów (książąt), posiadający własne korzenie duchowe, rozpoczął się wraz z pojawieniem się chrześcijaństwa na Rusi, a szczególny jego rozwój datowany jest na okres niewoli tatarskiej $^{16}$. W istocie kult ten na pewien czas jakby zastąpił kult świątobliwych, który przygasł w związku z najazdami tatarskimi na Ruś i zniszczeniem ośrodków monastycznych. Właśnie w okresie niewoli tatarskiej kult świętych władców osiągnął swój największy rozkwit, a jak zauważa Gieorgij Fiedotow, „ustaje wraz z zrzuceniem jarzma niewoli pod koniec XV wieku"17. Jednocześnie autor ten czyni istotne spostrzeżenie, że w porównaniu z bizantyjskimi cesarzami „książę ruski reprezentuje nie tyle władzę, co posługę", że

\footnotetext{
11 W Kościele Zachodnim okresem, który wydał najwięcej świętych władców, było późne średniowiecze.

12 G. Fiedotow, Święci Rusi (X-XVII w.), przekł. ks. H. Paprocki, Białystok - Bydgoszcz 2002, s. 74.

13 Wykaz takich władców patrz np.: W.M. Żywow, Swjatost', dz.cyt., s. 22.

14 E.N. Nikulina, Agiołogija, dz.cyt., s. 242-243.

15 E.W. Tkaczow, (hasło) Kanonizacja, [w:] Prawosławnaja encikłopiedija, t. 30, Moskwa 2012, s. 277; tenże autor podaje imiona dziewięciu innych świętych władców bizantyjskich z różnych wieków, którzy nie znaleźli się w wykazie Eugeniusza Gołubińskiego, a którzy odbierali bądź w dalszym ciągu odbierają kult jako święci.

16 Por. A.N. Sacharow, Swjatost' i swjatyje $w$ istorii Rossii, [w:] Problema swjatych i swjatosti $w$ istorii Rossii. Materiały XX Miezdunarodnogo seminaria istoriczeskich issledowanij „Ot Rima $k$ Tret'jemu Rimu”, red. A. N. Sacharow i P. Catalano, Moskwa 2006, s. 41 i n.

17 G. Fiedotow, Święci Rusi..., dz.cyt., s. 73. Nie jest to do końca zgodne z rzeczywistością, bowiem również w późniejszym czasie oddawano cześć tragicznie zmarłemu w mało przejrzystych okolicznościach (niekanonizowanemu) carowi Pawłowi I (+1801), a później wspomnianemu już carowi Mikołajowi II, zamordowanemu w 1918 r. przez komunistów. Ten okres historii, po XVIII w., nie był jednak już przedmiotem jego pracy.
} 
„gdy tylko Ruś przyjęła grecki ideał władzy i przeniosła go, wraz z carskim tytułem, na wielkich książąt moskiewskich, nastapił upadek ideału świętości lokalnych książąt". Badacz ten konstatuje: „kanonizacja książąt nie ma nic wspólnego z uświęceniem władzy”18. I rzeczywiście, zaliczeni do grona świętych książęta ruscy pełnili nie tyle rolę władców-polityków, co przywódców wojskowych. Dlatego też Kościół czci ich nie tyle jako władców, a jako działaczy narodowych, przywódców ludu.

Kanonizowani święci władcy pochodzą głównie z kręgów bizantyjskich (w pierwszym tysiącleciu) i ruskich (w drugim tysiącleciu). Ihumen Andronik (Trubaczow) podaje, że w gronie prawowiernych w Rosyjskim Kościele Prawosławnym znajduje się około pięćdziesięciu władców, zarówno tych czczonych w całym Kościele, jak i lokalnie ${ }^{19}$. Jednak ten typ świętości obecny jest również w innych Kościołach prawosławnych: np. w Kościele Gruzińskim (np. księżna męczennica Szuszanik, +475; książęta męczennicy Dawid i Konstantyn, +740), Bułgarskim (np. książę Borys, +907; książę Piotr, +967), Czeskim i Słowackim (np. księżna Ludmiła, +927; książę Wiaczesław-Wacław; +936), a szczególnie w Kościele Serbskim (np. męczennik Jan -Włodzimierz, +1016; król Władysław, +1239) ${ }^{20}$.

Dokonując wewnętrznej systematyki tego typu świętości, analizując przy tym ruską świętość, Gieorgij Fiedotow dzieli świętych książąt na kilka grup: „książąt równych apostołom, książąt-mnichów, książąt-strastotierpców i w końcu książąt, którzy zasłynęli działalnością społeczną"21. Do pierwszej grupy zalicza on: wielką księżną Olgę (+969) oraz wielkiego księcia Włodzimierza $(+1015)$, do drugiej m.in. księcia Mikołaja Światoszę $(+1142)$, do trzeciej m.in. książąt Borysa i Gleba $(+1015)$ oraz Andrzeja Bogolubskiego (+1174), a do czwartej m.in. Aleksandra Newskiego $(+1263)$. Podział ten wydaje się być o tyle niepełny, że do trzeciej z grup zalicza on zarówno książąt, którzy ponieśli śmierć z rąk swych współwyznawców (strastotierpcy - cierpiętnicy), jak i z rąk innowierców, co w zasadzie uprawniałoby tych drugich również do zaliczenia do kategorii męczenników ${ }^{22}$.

Termin „cierpiętnicy” (gr. 'A meрnuы) odnosi się w zasadzie niemal wyłączenie do świętych władców i jest charakterystyczny zasadniczo dla ruskiej świętości²3.

\footnotetext{
18 Tamże, s. 74.

19 Andronik (Trubaczow), ihumen, Błagowiernyj, dz.cyt., s. 252. W tabeli przedstawiającej statystyczne dane dotyczące świętych Kościoła Rosyjskiego na początek września 1999 r. M.A. Lukszina podaje cyfrę 58 kanonizowanych władców, z czego 12 kobiet; Andronik (Trubaczow), ihumen, (hasło) Kanonizacija swjatych w Russkoj Prawosławnoj Cerkwi, [w:] Prawosławnaja encikopiedija, t. 0, s. 369.

20 Por. przykłady podane w: Andronik (Trubaczow), ihumen, Błagowiernyj, dz.cyt., s. 251. Por. także m.in. najnowszą pracę poświęconą serbskim świętym władczyniom: D. Gapska, Dni pamięci świętych władczyń w kalendarzu serbskiej Cerkwi prawosławnej, [w:] Latopisy Akademii Supraskiej. Vol. 4. Kalendarz w życiu Cerkwi $i$ wspólnoty, pod. red. M. Kuczyńskiej i U. Pawluczuk, Białystok 2013, s. 49-58.

21 G. Fiedotow, Święci Rusi..., dz.cyt., s. 75.

22 W kościelnych kalendarzach męczennikami tytułowani są np. książę czernihowski Michał (+1245) czy książę riazański Roman (+1270)

23 Z odniesieniem „ruskości” fenomenu cierpiętnictwa i odniesieniem go
}

W szerokim znaczeniu termin „cierpiętnik” można być używany wobec wszystkich chrześcijańskich męczenników, którzy doznali cierpień i ponieśli śmierć za Chrystusa. Cierpiętnikiem może być nazwany każdy męczennik, który doświadczył cierpień (gr. $\pi \dot{\alpha} \theta o \varsigma, \pi \dot{\alpha} \theta \eta \mu \alpha$, łac. passio) $\mathrm{w}$ imię Zbawiciela ${ }^{24}$. Zasadniczo termin ten używany jest jednak w wąskim znaczeniu. Stosowany jest on w odniesieniu do tych świętych, którzy ponieśli śmierć nie z rąk prześladowców chrześcijaństwa, lecz nawet z rąk swych współwyznawców - „morderców i złoczyńców”25, „z powodu ich gniewu, podstępu, zmowy"26. Ich śmierć nie była przy tym związana z groźbami, następstwem których miałoby być wyrzeczenie się wiary w Chrystusa ${ }^{27}$. $\mathrm{W}$ ich zachowaniu podkreślany jest szczególny charakterach postawy - dobrowolne wyzbycie się władzy książęcej i wojskowej oraz związanej z nią możliwości do obrony, zaniechanie użycia siły $\mathrm{w}$ walce $\mathrm{z}$ wrogiem, nie przeciwstawiania się złu siłą, stanowiące naśladownictwa samego Jezusa Chrystusa.

Dobrowolnego poniżenie się i cierpień oraz gotowości na śmierć cierpiętnik dokonuje w imię doskonałego wypełnienia Ewangelii, zgodnie z którą swoją osobą składał on ofiarę, naśladując tym samym śmierć Chrystusa na Krzyżu (por. Fil 2,5-11). To przejaw walki duchowej mającej miejsce w duszy cierpiętnika, w której występuje on jako sługa i męczennik Chrystusowy. Przy tym - jak pisał Gierogij Fiedotow - „Kościół ruski nie czynił różnicy między śmiercią za wiarę Chrystusa i śmiercią będącą naśladowaniem Chrystusa” ${ }^{28}$. Cierpiętnicy „nie byli męczennikami wprost za Chrystusa, ale zachowali chrześcijańską postawę podczas swej męki”29 - pisał Jan Gajek. Ewangeliczne pocho-

do świętych władców ruskich trudno byłoby dyskutować, bowiem Ziemia Ruska dostarczyła ku temu nazbyt wielu przykładów; por. np. Z. Nowicki, Strastotierpcy, „W drodze”, 2000, nr 7, s. 80-88. Jednak za wzorzec cierpiętnictwa jako takiego można też uznać św. Dulę, mnicha egipskiego, który w kalendarzach kościelnych tytułowany jest właśnie cierpiętnikiem. Żył on prawdopodobnie w V w. i cechowa się wyjątkową pokorą i dobrotliwością. Przez 20 lat ze strony współbraci doświadczał wyjątkowego poniżania, a za jakoby dokonaną przez niego kradzież naczyń oraz inne zmyślone przestępstwa, został pozbawiony godności mnicha i poddany licznym katuszom. Został wtracony do więzienia, zakuty w dyby, bity, podpalany węglami, a nawet skazany na odcięcie rąk. Wszystko wyjaśniło się jednak, a Dulę zwolniono z więzienia. Jednak trzy dni później zmarł. Niekiedy czyniona jest analogia pomiędzy rosyjskim terminem „cierpiętnik” a greckim terminem „etnomartiros” (dosł. męczennik narodu). Jednak, wydaje się, że termin „męczennik narodu” jest znaczenie bliższy typowemu męczeństwu, które jest wynikiem prześladowań nie ze strony swych współwyznawców a innowierców.

24 Wobec cierpiętników ks. Władysław Cypin używa dosyć sztucznego terminu „męczennicy-cierpiętnicy”, W. Cypin, ks., Kurs cerkownogo pra$w a$, Klin 2002, s. 495. Termin „cierpiętnik” jest podawany jako synonim terminu „męczennik” w XIX-wiecznych rosyjskich słownikach, zarówno językowych, jak i teologicznych, O znaczenii słowa 'stastotierpiec', http:// pisma08.livejournal.com/55607.html [dostęp 10.01.2014]. Potwierdzeniem tego może być używanie tego terminu w modlitwach kierowanych do męczenników, np. kondakionie wspólnym do męczenników, kondakionie do męczennicy Tatiany czy wychwalaniu do św. męcz. Gabriela Zabłudowskiego.

25 A.Ju. Kostin, Niebiesnyje zastupniki, Moskwa 2004, s. 10.

26 W.M. Żywow, Swjatost'..., dz.cyt., s. 22.

27 Andronik (Trubaczow), ihumen, Błagowiernyj, dz.cyt., s. 252

28 G. Fiedotow, Święci Rusi..., dz.cyt., s. 31.

29 J.S. Gajek, U początków świętości Rusi Kijowskiej, [w:] Chrystus zwyciężył. Wokół Chrztu Rusi Kijowskiej, Warszawa 1989, s. 97. 
dzenie samej idei dobrowolności ofiary w imię Chrystusa (chociaż nie za wiarę) jest więc tu oczywiste ${ }^{30}$. Cierpiętnik zatem, „to ten, kto doświadczył gwałtownej śmierci nie za Chrystusa, lecz w imię dobrej sprawy i, będąc chrześcijaninem uznał to za krzyż Boży"31. Kluczowe znaczenie posiada tu również inna bardzo ważna chrześcijańska cnota - miłość, „której najwspanialszym wyrazem jest oddanie swego życia 'za przyjaciół swoich". Fiedotow nazywa wręcz cierpiętnictwo „najbardziej zdecydowanym odrzuceniem życia w świecie, ostatecznym wyrazem ascezy"32.

Badacze upatrują w cierpiętnikach oddzielnego „najbardziej paradoksalnego"33 typu świętości. Przy tym często nazywają go „typem ruskiej świętości”,34, „właściwie ruskim, wyrażającym szczególny rosyjski ideał świętości”' ${ }^{35}$, „charakterystycznym dla duchowości rosyjskiej”36 czy też „znanym szczególnie na Rusi”37. Omawiając żywoty świętych książąt Borysa i Gleba Iwan Kołogriwow pisze wręcz, że $\mathrm{w}$ ich osobach mamy do czynienia $\mathrm{z}$,pojawieniem się nowego typu świętości”38.

Wydzielenie cierpiętnictwa jako oddzielnej kategorii świętości wydaje się być zabiegiem na wyrost. „Umiłowawszy strastotierpców Kościół ruski nie wydzielił ich spośród męczenników" - pisze Fiedotow ${ }^{39}$. Badacz ten uważał cierpiętników za "najwyższy wyraz świętości książęcej”" Cierpiętnictwo należałoby więc uznać za rodzaj czy grupę świętości w ramach kategorii męczenników. Nie wydaje się przy tym konieczne ograniczanie tego fenomenu wyłącznie do świętych władców, jako że idea cierpiętnictwa, chociaż $\mathrm{w}$ ograniczonym stopniu, obecna jest również $\mathrm{w}$ innych warstwach społecznych.

Największym, „wzorcowym” przykładem cierpiętnictwa ruskiego są książęta Borys i Gleb (+1015), młodsi synowie równego apostołom wielkiego księcia Włodzimierza - pierwsi święci kanonizowani przez Kościół Ruski. W tym miejscu warto jednak przypomnieć również postacie świętych książąt: Igora Olegowicza (+1147), Andrzeja Bogolubskiego (+1174) czy Michała Jarosławowicza (+1318). Chociaż w kalendarzach cerkiewnych przy ich imionach brakuje słowa „cierpiętnik”, to nie ma wątpliwości, że właśnie do tej grupy świętych powinni oni być zaliczeni ${ }^{41}$. Naj-

\footnotetext{
30 G. Fiedotow, Święci Rusi..., dz.cyt., s. 29.

31 K. Parchomienko, ks., O swjatosti $i$ swjatych, http://azbyka.ru/ parkhomienko/otvety_svyaschennika_na_voprosy_14-all.shtml [dostep 30.01.2014]

32 Tamże, s. 230. Dosyć niepełną definicje cierpiętnictwa podaje też I. Kołogriwow; patrz: Ioann (Kołogriwow), ijeromonach, Oczerki po Istorii Russkoj Swjatosti, Bruksela 1961, s. 27.

33 G. Fiedotow, Święci Rusi..., dz.cyt., s. 30.

34 Tamże.

35 Ioann (Kołogriwow), ijeromonach, Oczerki..., dz.cyt., s. 23.

G. Skowrońska-Płaczynta, O kategoriach świętych $w$ prawosławiu $i$ ekwiwalentach ich rosyjskich nazw w języku polskim, [w:] Z problemów przekładu i stosunków międzyjęzykowych, pod red. T. Żeberek i T. Boruckiego, Kraków 2002, s. 182.

37 G. Skowrońska-Płaczynta, Swjatost' i swjatyje w Russkoj prawosławno cerkwi, [w:] Rusistika i sowremiennost'. Jazykoznanije, red. M. Bobran, WSP, Rzeszów 1999, s. 324.

38 Ioann (Kołogriwow), ijeromonach, Oczerki..., dz.cyt., s. 23.

39 G. Fiedotow, Święci Rusi..., dz.cyt., s. 31.

40 Tamże, s. 89.

41 Tamże, s. 80-83.
}

bardziej znane i wymowne (poza wspomnianymi Borysem i Glebem) przykłady świętych cierpiętników to carewicz uglicki i moskiewski Dymitr (+1591) oraz kanonizowany w 2000 r. car Mikołaj II z rodziną (+1918). Wraz z kanonizacją tych ostatnich w $2000 \mathrm{r}$. (car Mikołaj II z rodziną - jako męczennicy za wiarę - już w 1928 r. zostali kanonizowani przez tzw. Kościół Katakumbowy, w 1938 r. przez Kościół Serbskim, a w 1981 r. przez Rosyjskiej Kościół Prawosławny za Granicą) termin „cierpiętnik” został odświeżony i zajaśniał nowym blaskiem.

Czytelniejszy, ale nieco uproszczony, wydaje się być podział świętych władców ruskich zaledwie na dwie grupy: książąt-rycerzy i książąt-mnichów, dokonany przez Andreja Zajcewa. Ze względu na niewielką, zaledwie kilkuosobową, liczbą książąt-męczenników, kwalifikuje on ich bezpośrednio do kategorii męczenników ${ }^{42}$. Tenże autor wydziela dwa modele żeńskiej świętości władczyń Rusi. Jedne księżne, w pragnieniu zachowania wierności małżeńskiej, ponoszą śmierć, a zatem mogą być tytułowane prawowiernymi męczennicami (np. Julianna, księżna wiaziemska, +1406), inne prowadzą wyjątkowo pobożne życie, pomagają Kościołowi i ubogim, a niejednokrotnie składają też śluby monastyczne (np. Julianna, księżna łazarewska, +1604$)^{43}$. Równą apostołom wielką księżnę Olgę umieszcza on poza tymi modelami, podkreślając, że „Kościół wysławił ją za to, że jako pierwsza spośród władców Rusi przyjęła prawosławie i przygotowała glebę pod Chrzest Rusi”"44.

Klasyfikacja Zajcewa nie jest jednak kompletna. Wymyka się jej bowiem grupa księżnych, które nie tyle na łożu śmierci, co znaczenie wcześniej wybrały życie monastyczne, np. Anna, księżna nowogródzka (+1051) czy Eufrozyna, księżna połocka (w życiu świeckim Predsława) (+1173). $\mathrm{W}$ przypadku tej grupy świętych istnieje problem związany $\mathrm{z}$ nazewnictwem, bowiem niekiedy tytułowane są one prawowiernymi, a innym razem świątobliwymi, a niekiedy przy ich imieniu występują oba określenia. Jeszcze mniej zrozumiałe wydaje się nazewnictwo używane wobec świętej Zofii, księżnej słuckiej (+1612), nie wiadomo dlaczego nazywanej „sprawiedliwą” (gr. $\Delta i \kappa \alpha \iota l$, cs. праведные) zamiast „prawowierną". Wydaje się, że najbardziej zasadne i klarowne byłoby używanie w nazewnictwie władców ich zasadniczej kategorii świętości, tj. określenia „prawowierny/prawowierna", chyba że władca ów został mnichem (mniszką), co upoważniałoby do nazewnictwa w rodzaju „świątobliwa N., księżna ... (podanie tytułu książęcego)”.

Podsumowując powyższe, najbardziej klarowny wydaje się być podział świętych władców na następujące grupy:

- władca/władczyni, nie będący ani męczennikiem, ani mnichem/mniszką, ani cierpiętnikiem (nazwa: prawowierny/prawowierna $N$., książę/księżna...),

- władca/władczyni, którzy zakończyli swoje życie śmiercią męczeńską (nazwa: męczennik/męczennica N., książę/księżna...),

- władca/władczyni, którzy nie na łożu śmierci, lecz

\footnotetext{
42 A. Zajcew, Żitija swjatych. Putiewoditiel', dz.cyt., s. 98.

43 Tamże, s. 135-136.

44 Tamże, s. 135.
} 
wcześniej złożyli śluby monastyczne i wiedli żywot mnisi (nazwa: świątobliwy/świątobliwa N., książę/księżna...),

- władcy/władczynie - cierpiętnicy (nazwa: cierpiętnik/cierpiętnica N., książę/księżna...).

Władców tytułowanych „równymi apostołom” nie należałoby wyodrębniać w osobną grupę, bowiem nie jest to kategoria świętości, lecz honorowy tytuł.

Zaproponowane nazewnictwo $\mathrm{z}$ jednej strony wska- zywałoby zarówno na pochodzenie świętego z rodu władców, określałoby jego dalszą drogę życiową (o ile miała ona miejsce) oraz rodzaj śmierci, a z drugiej nie wprowadzałoby zamieszania i niekonsekwencji w określeniach używanych przy imionach świętych władców. Byłoby to również klarowne z punktu widzenia określenia do jakich (jednej czy dwóch) kategorii świętości daną osobę można zakwalifikować.

\section{Bibliografia:}

Andronik (Trubaczow), ihumen, (hasło) Błagowiernyj, [w:] Prawosławnaja encikłopiedija, t. 5, Moskwa 2002.

Andronik (Trubaczow), ihumen, (hasło) Kanonizacija swjatych w Russkoj Prawosławnoj Cerkwi, [w:] Prawosławnaja encikopiedija, t. 0 .

Euzebiusz z Cezarei, Życie Konstantyna, wstęp, przekł. T. Wnętrzak, ŹMT 44, Kraków 2007.

Cypin W., ks., Kurs cerkownogo prawa, Klin 2002.

Fiedotow G., Święci Rusi (X-XVII w.), przekł. ks. H. Paprocki, Białystok - Bydgoszcz 2002.

Gajek J. S., U początków świętości Rusi Kijowskiej, [w:] Chrystus zwyciężył. Wokół Chrztu Rusi Kijowskiej, Warszawa 1989.

Biskup Hilarion Ałfiejew, Prawosławie, t. I, Moskwa 2008.

Ioann (Kołogriwow), ijeromonach, Oczerki po Istorii Russkoj Swjatosti, Bruksela 1961.

Kostin A. Ju., Niebiesnyje zastupniki, Moskwa 2004.

Nikulina E. N., Agiołogija, Moskwa 2009.

Nowicki Z., Strastotierpcy, „W drodze”, 2000, nr 7.

O znaczenii słowa „stastotierpiec”, http://pisma08.livejournal. com/55607.html [dostęp 10.01.2014].

Parchomienko K., ks., O swjatosti i swjatych, http://azbyka.ru/par- khomienko/otvety_svyaschennika_na_voprosy_14-all.shtml [dostep 30.01.2014].

Sacharow A. N., Swjatost' i swjatyje w istorii Rossii, [w:] Problema swjatych i swjatosti w istorii Rossii. Materiały XX Mieżdunarodnogo seminaria istoriczeskich issledowanij „Ot Rima $k$ Tret'jemu Rimu”, red. A. N. Sacharow i P. Catalano, Moskwa 2006.

Skowrońska-Płaczynta G., O kategoriach świętych w prawosławiu $i$ ekwiwalentach ich rosyjskich nazw w języku polskim, [w:] Z problemów przekładu i stosunków międzyjęzykowych, pod red. T. Żeberek i T. Boruckiego, Kraków 2002.

Skowrońska-Płaczynta G., Swjatost' i swjatyje w Russkoj prawosławno cerkwi, [w:] Rusistika i sowremiennost'. Jazykoznanije, red. M. Bobran, WSP, Rzeszów 1999.

Srezniewski I. I., Materiały dla słowaria drewnierusskogo jazyka po pismiennym pamjatnikam, Sankt Petersburg 1893, t. I.

Tkaczow E. W., (hasło) Kanonizacja, [w:] Prawosławnaja encikłopiedija, t. 30, Moskwa 2012.

Zajcew A., Żitija swjatych. Putiewoditiel', Moskwa 2008.

Znosko A., ks., Słownik cerkiewnosłowiańsko-polski, Białystok 1996.

Żywow W. M., Swjatost'. Kratkij słowar' agiograficzeskich terminow, Moskwa 1994. 
ISSN 1508-7719

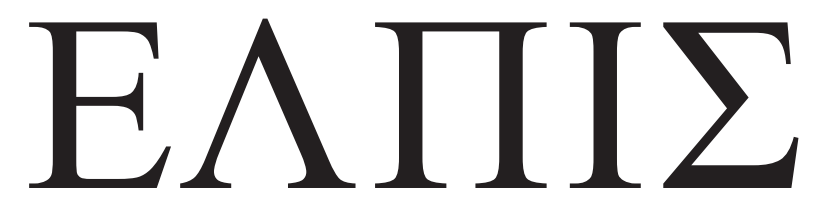

CZASOPISMO TEOLOGICZNE KATEDRY TEOLOGII PRAWOSŁAWNEJ UNIWERSYTETU W BIAŁYMSTOKU

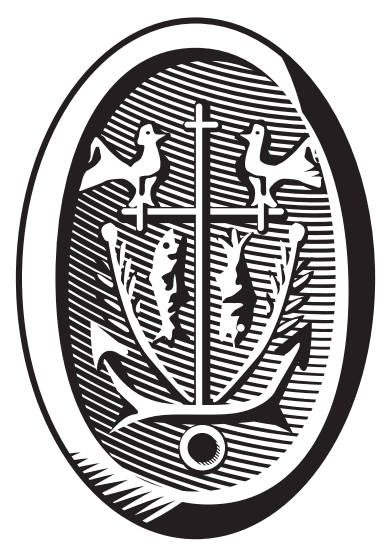

ADRES REDAKCJI

15-097 Białystok, ul. M. Skłodowskiej-Curie 14 tel. 85 745-77-80, e-mail: redakcja@elpis.edu.pl www.elpis.uwb.edu.pl 